\title{
Jewish Music
}

Author(s): W. H. Grattan Flood

Source: The Musical Times, Vol. 55, No. 852 (Feb. 1, 1914), p. 104

Published by: Musical Times Publications Ltd.

Stable URL: http://www.jstor.org/stable/905748

Accessed: 07-05-2016 06:02 UTC

Your use of the JSTOR archive indicates your acceptance of the Terms \& Conditions of Use, available at

http://about.jstor.org/terms

JSTOR is a not-for-profit service that helps scholars, researchers, and students discover, use, and build upon a wide range of content in a trusted digital archive. We use information technology and tools to increase productivity and facilitate new forms of scholarship. For more information about JSTOR, please contact support@jstor.org.

Musical Times Publications Ltd. is collaborating with JSTOR to digitize, preserve and extend access to The Musical Times 
The Musical Directory, Annual, and Almanac, I9I4. Pp. 488. Price 3 s. net. (London : Rudall, Carte \& Co., Ltd.)

Choral Technique and Interpretation. By Henry Coward. Pp. 332. Price, 5s. net. (London: Novello \& Co., Ltd. New York: The H. W. Gray Co.)

Annuaire du Conservatoire Royal de Musique de Bruxelles. (36 année.) Pp. 205. (Bruxelles: Imprimerie A. Lesigne.)

Annuaire du Conservatoire Royal de Musique de Bruxelles. (37 année.) Pp. 22I. (Bruxelles: Imprimerie A. Lesigne.)

The Marie Tempest Birthday Book. Pp. 128. (London: Stanley Paul \& Co.)

Four Lectures on English Song. By W. Fothergill Robinson. Pp. 37. (Oxford : Messrs. Sydney Acott \& Co.) 'Lohengrin' and 'Parsifal.' By Alice Leighton Cleather and Basil Crump. Pp. $158+8$. Price 2s. $6 d$. (London: Methuen \& Co., Ltd.)

'Rhinegold,' 'The Valkyrie,' 'Siegfried,' 'Twilight of the gods,' 'Parsifal.' Operas by Richard Wagner. Vocal scores, with German text and an English translation by Ernest Newman. (London : Breitkopf \& Härtel.)

\section{Correspondence.}

\section{JEWISH MUSIC.}

TO THE EDITOR OF 'THE MUSICAL TIMES.'

SIR,-Mr. Arthur M. Friedländer, in his interesting 'Notes on facts and theories relating to Jewish music [January number, p. 2I], does not appear to have read Gastoué's monumental work, 'Les origines du Chant Romain' (Paris, I907), in which the opening chapter deals with the Jewish Liturgy. Gastoué points out that Psalm xc (Vulgate 9I, 'Bonum est confiteri Domino'), of which the original title is 'For the Sabbath,' still forms part of the Saturday office in the Synagogue and also in the Catholic Church. Again, he tells us that the rite of the Jewish office has numerous points of resemblance with that of the Christian Church.

As to the Te Deum generally known as the 'Ambrosian Te Deum,' Mr. Friedländer ought to be aware that its ascription to St. Ambrose is now discredited by hymnologists. It was most probably written by St. Niceta, of Remesiana in Dacia, as traced from Irish sources by Dom G. Moriu (see also the revised edition of Julian's 'Dictionary of hymnology,' London, I907). It would also be well to note the excellent article on the $\mathrm{Te}$ Deum by the Rev. Dr. Frere, in the new edition of Grove's 'Dictionary of music,' vol. v. (I9ro). And surely it might have been mentioned that the Hebrew cantillations were deciphered by Kircher and Munster. Father Munster, O.F.M., wrote his work in I 524, while that of Kircher appeared in I650. Yours faithfully,

January I, I9I4.

W. H. Grattan Flood.

\section{WAGNER IN PARIS.}

TO THE EDITOR OF 'THE MUSICAL TIMES.'

Sir,-The decease of Baron Emile d'Erlanger (I imagine about the last survivor of those who worked in Paris in the interest of Wagner) brought back to my memory part of a story told me at the time by Alexandre Reichardt, a very old and dependable friend, a well-known opera-singer, who vouched for its truth. Such a scene could not be invented, and certainly I have never seen it referred to in print.

The Baron did much for Wagner in getting 'Tannhäuser' produced, but the one who actually contrived the feat was Princess Metternich, wife of the ambassador. It was brought about in this way: The Princess was getting up 'charades' before the Emperor, Empress, and full Court, and before the curtain opened she asked the Emperor if, provided he failed in guessing the particular one she appeared in, he would promise to grant a request she would make, and to this he acceded.
The charade opened with a scene the particulars of which I have forgotten-beyond that, as a whole, it represented the syllable ME or MET. In Scene 2, the Princess was discovered on bended knee holding a flower-pot saucer full of earth on her hand, reading as TER (RE). The opening of the curtain on Scene 3 created a marvellous sensation, when the Princess was again discovered, but this time with fingers extended from her nose and pointed at the Emperor. Most of the guests rose excitedly, imagining the Princess must have gone mad to have dared such a deed. The Emperor seemed for a time dangerous to speak to ; at las the silence was broken by the Princess asking if His Majesty had guessed the whole. He replied he had failed to do so, and must thereon pay the penalty. She in explanation said the whole spelt her own name, the last syllable NICH being sometimes expressed (though perhaps not in the very highest society) by the finger sign.

After some further hesitation the Emperor desired the Princess to prefer her request; and she did in plain terms, that His Majesty would graciously command that Wagner's opera should be produced, and in fulfilment of his promisebut seemingly unwillingly-he gave orders for its production. -Yours faithfully,

Tunbridge Wells.

Charles J. HargitT.

[The influence of the Princess Metternich in getting 'Tannhäuser' performed in Paris is acknowledged by Wagner in his 'My life' (p. 736, English edition). He says: 'Suddenly, one morning, Count Hatzfeld overwhelmed me with the news that on the preceding evening the Emperor had given orders for a performance of my "Tannhäuser." The decisive word had been spoken by Princess Metternich. As I happened to be the subject of conversation near the Emperor she had joined the circle, and on being asked for her opinion, she said she had heard "Tannhäuser" at Dresden, and spoke in such enthusiastic terms in favour of it that the Emperor at once promised to give orders for its production. It is true that Fould, on receiving the imperial command the same evening, broke out into a furious rage, but the Emperor told him he could not go back upon his promise, as he had pledged his word to Princess Metternich.'-(ED., M.T.)]

\section{OPERA AT BOURNEMOUTH.}

TO THE EDITOR OF 'THE MUSICAL TIMES.'

SiR,-Mr. Manners takes exception, in the most courteous way imaginable, to my little criticism of his production of 'Lohengrin' at Bournemouth, and in doing so specifically quotes and dwells upon my use of the words "incomplete performance.' Without any concealment or suggestion of disguise Mr. Manners himself reveals the nature of the deficiency. He says, "I candidly confess that my orchestra was a weak point,' but quite rightly he imputes no blame to the incorporated local players, who admittedly can in no way be expected to perform prodigious feats after but a short rehearsal and under a strange conductor. The admission made by Mr. Manners relieves me of any further discussion of the question. I would merely venture to remark that, in common with many other people, I hold that Wagner's works (above all others, perhaps) are best left alone unless a thoroughly satisfactory and sound orchestral rendering is assured.

Mr. Manners further institutes a comparison between his own company and one which he recently heard at Aix-la-Chapelle.

Nothing is further from my desire than to draw a parallel between the company that Mr. Manners directs and those upon the Continent, where the conditions for the advancement of opera are so much more beneficent. The problem is an English one, and concerns English effort alone. I would merely express the hope that Mr. Manners will believe that I have never wittingly said or written anything that might be considered as opposed to the best interests of either opera in English or English opera-both of which I value very highly-and that I am fully conscious of the yeoman service that Mr. Manners has accomplished in a cause that all genuine lovers of music should have very near to their hearts. - I am, \&c., Your Corresponident.

January I 5 , I9I4. 